\title{
Analisis Pengelolaan Keuangan Kampung Hinekombe (Studi Empiris Pada Distrik Sentani Kabupaten Jayapura) \\ Fredi Enumbi ${ }^{1}$ \\ fredienumbi@gmail.com \\ Paulus K. Allolayuk ${ }^{1}$ \\ Mariolin A. Sanggenafa ${ }^{1}$ \\ Jurusan Akuntansi, Fakultas Ekonomi dan Bisnis Universitas Cenderawasih
}

\begin{abstract}
The objectives of this study are (1) To determine village financial management in Hinekombe Village, Sentani District, Jayapura Regency in accordance with Minister of Home Affairs Regulation Number 20 of 2018 concerning Village Financial Management. (2) To find out the obstacles faced by the village government in financial management and accountability in Hinekombe Village, Sentani District, Jayapura Regency. This research method is descriptive using a qualitative approach, data collection techniques through observation, interviews and literature study. The primary data sources were interview data and secondary data from the hinekombe village profile. The research informants were 10 people.

The results show that (1) the government of Hinekombe Village, Sentani District, Jaypura Regency is good enough in managing village finances in accordance with Permendagri Number 20 of 2018 concerning Village Financial Management. This shows that the Hinekombe Village Government has tried its best to be able to implement the central government regulations on village financial management even though there are some activity items that are incomplete in their reporting. (2) Constraints faced by the village government in financial management in Hinekombe Village, Sentani District, Jayapura Regency. Namely, community self-help is still lacking, supervision is also lacking. In addition, budget changes were not carried out through deliberations with community leaders or unilaterally by the Hinekombe Village Government Apparatus which made the community less confident in financial management carried out by the hinekombe village government.
\end{abstract}

Keywords: Financial Management; Hinekombe Village.

\section{Abstrak}

Tujuan dari penelitian ini adalah (1) Untuk mengetahui pengelolaan keuangan desa di Kampung Hinekombe Distrik Sentani Kabupaten Jayapura sesuai dengan Permendagri Nomor 20 tahun 2018 Tentang Pengelolaan Keuangan Desa. (2) Untuk mengetahui kendala-kendala yang dihadapi pemerintah kampung dalam pengelolaan dan pertanggung jawaban keuangan di Kampung Hinekombe Distrik Sentani Kabupaten Jayapura.

Metode penelitian ini adalah deskriptif menggunakan pendekatan kualitatif . Sumber data primer yaitu data wawancara dan data sekunder profil kampung hinekombe. Informan penelitian sebanyak 10 orang. Teknik pengumpulan data melalui observasi, wawancara dan studi pustaka. Metode analisis yaitu reduksi data, pengelompokan data, display data dan penarikan kesimpulan.

Hasil penelitian menunjukkan bahwa (1) Pemerintah Kampung Hinekombe Distrik Sentani Kabupaten Jayapura sudah cukup baik dalam melakukan pengelolaan keuangan kampung sesuai dengan Permendagri Nomor 20 tahun 2018 Tentang Pengelolaan Keuangan Desa. Hal ini menunjukkan bahwa Pemerintah Kampun Hinekombe telah berusaha bekerja dengan maksimal untuk dapat mengimplementasikan peraturan pemerintah pusat tentang pengelolaan keuangan kampung walaupun ada beberapa item kegiatan yang kurang tidak lengkap dalam pelaporannya. (2) Kendala-kendala yang dihadapi pemerintah kampung dalam pengelolaan keuangan di Kampung Hinekombe Distrik Sentani Kabupaten Jayapura.yaitu Swadaya Masyarakat masih kurang, pengawasan juga masih kurang. Selain itu juga perubahan anggaran tidak dilakukan melalui musyawarah dengan tokoh masyarakat atau sepihak oleh Aparatur Pemerintah Kampung Hinekombe yang membuat masyarakat kurang begitu percaya terhadap pengelolaan keuangan yang dilakukan pemerintah kampung hinekombe.

Kata kunci : Pengelolaan Keuangan, Kampung Hinekombe. 


\section{Pendahuluan}

Desa merupakan suatu langkah awal kemandirian desa dalam penyelenggaraan Pemerintah maupun dalam pengelolaan dana desa. Dalam pelaksanaannya desa akan bersentuhan langsung dengan masyarakat dalam peranan desa memberikan pelayanan kepada publik khususnya kepada masyarakat, maka diharapkan dalam penyelenggaraan pemerintah dan pengelolaan dana desa dibutuhkan aparat pemerintah desa yang handal serta sarana dan prasarana yang memadai agar pelaksanaannya lebih terarah dan sesuai dengan tata kelola yang baik (Shuha, 2018).

Pembiayaan merupakan faktor yang sangat menentukan dalam proses pembangunan. Target dalam suatu proses pembangunan haruslah jelas. Selama ini poemerintah telah mengalokasikan dana berupa Alokasi Dana Desa (ADD) dengan disertai berbagai petunjuk teknis agar penggunaan dana sesuai prinsip-prinsip ekonomi. Dengan dana yang terbatas hendaknya dipergunakan secara maksimal program serta penggunaan sebesar-besarnya untuk kesejahteraan dan kemakmuran rakyat serta pengembangan ekonomi masyarakat di desa. harus dapat dipertanggung jawabkan dengan beberapa indikator dan adanya kesesuaian antara tujuan dan sasaran pembangunan desa (Lili, 2018).

Dewasa ini pemerintah Indonesia terus berusaha melakukan peningkatan pelaksanaan pembangunan nasional agar pertumbuhan pembangunan daerah serta pembangunan desa dan kota semakin seimbang, namun pada pelaksanaannya masih ada beberapa masalah seperti ketidaksesuaian pembangunan antara desa dengan kota di Indonesia. Menanggapi permasalahan tersebut, pemerintah membuat strategi untuk mengatasi ketidaksesuaian pembangunan yaitu dengan adanya dana desa. pemerintah, pelaksanaan pembangunan, pembinaan, dan pemberdayaan masyarakat.

Berdasarkan hasil observasi awal penulis di lokasi penelitian dimana menurut informasi dari beberapa masyarakat kampung Hinekombe dikatakan bahwa : Pertama, Selama ini Pembangunan di kampung ini sangat jarang dilakukan. Setiap ada pencairan dana, sangat jarang diadakan musyawarah dengan kami masyarakat. Kalaupun ada itu hasil rapat juga tidak dijalankan Contohnya pembangunan jalan, sarana - prasarana lain di kampung sudah dibahas dan diprogramkan tapi juga tidak dijalankan, program pemberdayaan masyarakat juga jarang dibantu oleh pemerintah desa. Kedua, dalam perencanaan mengalokasikan dana desa, yakni dalam mengalokasikan dana desa untuk pembangunan desa dan pemberdayaan masyarakat desa di Kampung Hinekombe kurang dari $70 \%$ dari dana yang diperoleh, hal ini tidak sesuai dengan Ketiga, dalam hal pertanggungjawaban, dari pemerintah Kampung Hinekombe kepada Pemerintah Distrik Sentani mengalami keterlambatan dalam penyampaian pertanggungjawaban kepada Bupati, untuk APBDesa tahun 2018 pada tahap pertama, perangkat nagari menyampaikan laporan pertanggungjawaban kepada Bupati di bulan Oktober, seharusnya dilaporkan pada akhir bulan Juli. Keterlambatan ini mengakibatkan pencairan Dana Desa untuk tahap ke kedua juga akan ikut terlambat, hal ini tentunya akan menghambat penyelenggaraan pemerintah desa

Berdasarkan temuan awal di lokasi penelitian, nampaknya Pemerintah Kampung Hinekombe belum dapat mengelola keuangan desa secara maksimal dengan dukungan dana yang dimiliki. Karena masih penulis melihat banyak indikator kegiatan dalam RPJM yang belum sesuai atau tidak terlaksana.

Ketidakmampuan aparat desa dalam pengelolaan keuangan desa menunjukkan bahwa tingkat pengetahuan atau SDM dari aparatur desa sebagai pengelola keuangan desa dari pemerintah masih kurang. Tingkat partisipasi masyarakat kampung Hinekombe juga masih sangat kurang, hal ini bukan karena masyarakat tidak mau berpartisipasi dalam kegiatan pembangunan dari pemerintah kampung. Namun karena pemerintah kampung hanya melakukan wacana dan wacana tanpa realisasi pelaksanaan pembangunan yang nyata.

Penelitian ini mereplikasi penelitian yang dilakukan oleh Shuha (2018). Perbedaan penelitian penulis dengan penelitian terdahulu terletak pada lokasi dan tahun penelitian dimana penulis melakukan penelitian di Kampung Hinekombe, Distrik Sentani Kabupaten Jayapura pada tahun 2020. Sedangkan penelitian terdahulu dilakukan di Kecamatan Lubuk Alung Kabupaten Padang Pariama pada tahun 2018. Persamaan penelitian penulis dan penelitian terdahulu yaitu sama-sama meneliti tentang pengelolaan keuangan desa.

Berdasarkan beberapa temuan awal tersebut maka penulis tertarik untuk melakukan penelitian dengan judul "Analisis Pengelolaan Keuangan Kampung Hinekombe". Adapun rumusan masalah penelitian ini adalah 1) apakah pengelolaan keuangan desa di Kampung Hinekombe Distrik Sentani 
Kabupaten Jayapura telah sesuai dengan Peraturan Menteri Dalam Negeri Nomor 20 tahun 2018 Tentang Pengelolaan Keuangan Desa, 2) kendala-kendala apa saja yang dihadapi pemerintah kampung dalam melakukan pengelolaan keuangan desa di Kampung Hinekombe Distrik Sentani Kabupaten Jayapura. Dalam penelitian ini penulis hanya membatasi kajian permasalahan penelitian terkait pengelolaan keuangan desa sesuai Peraturan Menteri Dalam Negeri Nomor 20 tahun 2018 Tentang Pengelolaan Keuangan Desa, dan kendala-kendala saja dalam pelaksanaan pembangunan di Kampung Hinekombe Distrik Sentani Kabupaten Jayapura.

\section{Kajian Pustaka}

\subsection{Teori Akuntansi Sektor Publik}

Dalam beberapa hal, organisasi sektor publik memiliki kesamaan dengan sector swasta. Keduanya memakai sumber daya serupa untuk mencapai tujuannya dan memiliki kemiripan dalam proses pengendalian. Akan tetapi, untuk tugas tertentu keberadaan sektor publik tidak dapat digantikan oleh sektor swasta, misalnya fungsi birokrasi pemerintahan (Prabowo, 2007).

Berdasarkan dari pengertian tersebut, maka akuntansi sektor public dapat diartikan sebagai suatu aktivitas pemberian jasa untuk menyediakan informasi keuangan pemerintah yang mana berdasarkan proses pertama pencatatan, kedua pengklasifikasian, ketiga pengikhtisaran suatu transaksi keuangan pemerintah kemudian juga penafsiran dari sebuah informasi keuangan. Jadi secara umum pengertian akuntansi sektor publik tidak jauh berbeda dengan akuntansi bisnis, perbedaannya hanya terletak pada jenis transaksi yang dicatat dan penggunaannya. Jenis transaksi yang dicatat dalam akuntansi sektor public adalah transaksi keuangan pemerintah, sebagian akan memiliki karakteristik tersendiri yang membedakannya dengan akuntansi bisnis.

\subsection{Teori Siklus Manajemen Keuangan}

Siklus manajemen keuangan desa menurut Bastian (2015), pelaksanaan manajemen keuangan desa dilakukan secara sederhana berupa pencatatan penerimaan dan pengeluaran.

\subsection{Konsep Pengelolaan Keuangan}

Menurut Wardoyo (1980) memberikan definisi bahwa pengelolaan adalah suatu rangkaian keitan yang berintikan perencanaan, pengorganisasian, penggerakan dan pengawasan dalam mencapai tujuan yang telah ditetapkan sebelumnya.

\subsection{Tahapan Pengelolaan Keuangan Desa}

Menurut Peraturan Menteri Dalam Negeri Nomor 113 Tahun 2014 siklus Pengelolaan Keuangan Desa bisa dimulai dari perencanaan, kemudian diikuti dengan penganggaran, pelaksanaan, penatausahaan, pelaporan, pertanggung jawaban dan pengawasan.
a. Perencanaan
b. Pelaksanaan
c. Penatausahaan
d. Pelaporan
e. Pertanggung jawaban
f. Pengawasan

\subsection{Konsep Tentang Dana Desa}

Desa-desa di Indonesia akan mengalami reposisi dan pendekatan baru dalam pelaksanaan pembangunan dan tata kelola pemerintah desa. UU tersebut memberikan kewenangan luas kepada desa dibidang penyelenggaraan pemerintahan desa, pelaksanaan pembangunan desa, pembinaan kemasyarakatan desa, dan pemberdayaan masyarakat desa berdasarkan prakarsa masyarakat, hak asal usul, dan adat istiadat desa. Dengan kata lain, desa ditempatkan sebagai suatu organisasi pemerintahan yang secara politis memiliki kewenangan tertentu untuk mengurus dan mengatur warga atau komunitasnya (Winarni \& Yuanjaya, 2016).

\subsection{Faktor Penghambat Pengelolaan Keuangan Desa}

Implementasi pengelolaan keuangan desa yang dilakukan oleh aparat pemerintah desa yang 
sesuai dengan Peraturan Menteri Dalam Negeri Nomor 20 tahun 2018 tentang Pengelolaan Keuangan Desa memiliki hambatan, diantaranya sebagai berikut:
a. Sumber Daya Manusia
b. Swadaya Masyarakat
c. Pengawasan Masyarakat
d. Partisipasi Masyarakat
e. Perubahan Anggaran

\subsection{Tinjauan Empiris/Penelitian Terdahulu}

1. Shuha (2018) hasil penelitiannya menunjukkan bahwa (1) Perencanaan telah sesuai dengan Peraturan Menteri Dalam Negeri Nomor 113 Tahun 2014 tentang Pengelolaan Keuangan Desa.

2. Pradana (2018) hasil penelitiannya menunjukkan bahwa Pengelolaan keuangna desa di desa Jatimulyo secara umum sudah sesuai dengan Peraturan Menteri Dalam Negeri Nomor 113 Tahun 2014. Namun masih ada beberapa ketentuan yang belum dilakukan. Pertama, pada proses perencanaan keuangan desa masih mengalami keterlambatan dalam menetapkan Anggaran Pendapatan dan Belanja Desa karena ada peraturan baru yang muncul sehingga diperlukan penyesuaian.

3. Hutami (2017) penelitiannya menunjukkan bahwa Pertama, Proses Pengelolaan ADD meliputi Perencanaan, Pelaksanaan, Penatausahaan, Pelaporan dan Pertanggung jawaban. Pengelolaan ADD yang dilakukan oleh Pemerintah Desa Abbatireng Kecamatan Gilireng Kabupaten Wajo telah mengikuti aturan petunjuk teknis yang telah diatur dalam peraturan perundang-undangan. Namun dalam prosesnya masih belum optimal.

\section{Metode Penelitian}

\subsection{Lokasi Penelitian}

Penelitian ini dilakukan di Kantor Kampung Hinekombe Kabupaten Jayapura pada bulan Januari 2020.

\subsection{Jenis dan Sumber Data}

\subsubsection{Jenis Penelitian}

Jenis penelitian ini adalah deskriptif menggunakan pendekatan kualitatif. Untuk dapat mendeskripsikan dan mengungkap fakta-fakta sesuai tujuan penelitian ini terkait pengelolaan keuangan desa sesuai Peraturan Menteri Dalam Negeri Nomor 20 tahun 2018 Tentang Pengelolaan Keuangan Desa di Kampung Hinekombe Kabupaten Jayapura.

\subsubsection{Sumber Data}

Sumber data dalam penelitian ini yaitu data primer dan data sekunder, penjelasannya sebagai berikut :

a. Data primer

Data primer merupakan materi atau kumpulan fakta yang di kumpulkan sendiri dari peneliti pada saat penelitian berlangsung. Data primer penulis peroleh dengan cara melakukan wawancara langsung kepada beberapa aparat kampung Hinekombe, tokoh masyarakat dan warga masyarakat.

b. Data sekunder

Data sekunder merupakan data yang diperoleh penelliti dari pihak lain atau data yang diambil secara tidak langsung dari sumber data. data sekunder penulis peroleh dengan cara melakukan kajian seperti buku, asrip, dokumen dari Pemerintah Kampung Hinekombe Kabupaten Jayapura yang berkaitan dengan penelitian penulis.

\subsection{Informan Penelitian}

Pemilihan Informan dalam penelitian ini yaitu aparat pemerintah kampung Hinekombe yang mana mengetahui pengelolaan dana desa, aliran dana desa dan penggunaannya. Selai itu juga tokohtokoh masyarakat dan warga kampung yang mana sebagai pembanding informasi yang penulis peroleh dari Pemerintah Kampung Hinekombe. Dimana jumlah informan dalam penelitian yaitu 10 orang. Lebih jelasnya berikut ini :
a. Kepala Kampung
: 1 orang 


\begin{tabular}{ll} 
b. Sekretaris Kampung & $: 1$ orang \\
c. Bendahara Kampung & $:$ 1 orang \\
d. Kaur Keuangan & $:$ 1 orang \\
e. Ketua BAMUSKAM & $:$ 1 orang \\
f. Tokoh Adat & $: 1$ orang \\
g. Tokoh Pemuda & $: 1$ orang \\
h. Tokoh Perempuan & $:$ 1 orang \\
i. Tokoh Masyarakat & : 2 orang \\
\cline { 2 - 3 } Jumlah &
\end{tabular}

\subsection{Teknik Pengumpulan Data}

Dalam pengumpulan data ada beberapa teknik yang penulis gunakan, antara lain:

1. Wawancara (Interview) adalah suatu cara pengumpulan data yang dilakukan dengan cara sipeneliti mengajukan pertanyaan secara lisan kepada responden untuk memperoleh data yang diperlukan.

2. Study Pustaka, yaitu melakukan kajian buku-buku, literature, jurnal, artikel, dokumen-dokumen yang dapat mendukung hasil penelitian.

\subsection{Metode Analisis}

Analisis data adalah upaya mengorganisasikan dan mengurutkan data secara sistematis catatan wawancara dan lainnya untuk meningkatkan pemahaman peneliti tentang kasus yang diteliti. Tujuan dari analisis ini adalah untuk menggambarkan kejadian, yang faktual dan akurat mengenai fakta-fakta yang terjadi selama penelitian yang dilakukan. Adapun langkah-langkah yang dilakukan dalam menganilis data dalam penelitian ini adalah sebagai berikut:

\section{Reduksi Data}

Data-data yang berhasil diperoleh melalui observasi, wawancara, dan dokumentasi merupakan data mentah yang masih bersifat acak-acakan dan kompleks. Sehingga untuk memudahkan peneliti, perlu diadakan penyerdahanaan data.Penyerdarhanaan data tersebut dilakukan untuk menghasilkan data yang relevan dengan tujuan penelitian.

\section{Pengelompokan Data}

Data yang sudah disederhanakan pada tahap reduksi data, selanjutnya disusun dan dikelompokan secara sistematis ke dalam unit-unit sesuai dengan sifat masing-masing data.

\section{Display Data}

Pada tahap ini peneliti menyajikan data-data yang dipilih dan dikelompokkan secara sistematis dalam bentuk uraian sebagai sebuah laporan. Data disajikan dalam bentuk narasi berupa informasi mengenai hal-hal yang terkait dengan judul.

\section{Penarikan Kesimpulan dan Verifikasi}

Data yang telah diperoleh dan disusun dalam bentuk uraian naratif tersebut, selanjutnya dibuat kesimpulan. Kesimpulan tersebut kemudian diverifikasi selama penelitian berlangsung dengan cara melihat kembali pada hasil reduksi dan display data.

\subsection{Definisi Operasional Variabel Pengelolaan Keuangan Desa}

Pengelolaan keuangan desa mengikuti pola pengelolaan keuangan daerah (kabupaten/ kota/ provinsi) yang terdiri dari pendapatan, belanja dan pembiayaan yang ditetapkan dalam APBDes. Sesuai dengan ketentuan yang ditetapkan oleh pemerintah pusat yang mengacu pada Peraturan Menteri Dalam Negeri Nomor 20 tahun 2018, dimana dalam proses penganggaran melalui prosedur :

1. Perecanaan, yang dimaksudkan adalah tahapan perencanaan penggunaan dana desa yaitu pembuatan rencana.

2. Pelaksanaan, tahapan penggunaan dana atau pencairan dana desa

3. Penatausahaan, segala rangkaian kegiatan yang meliputi pembukuan, inventarisasi, dan pelaporan barang milik desa yang diperoleh dari hasil penggunaan dana desa 
4. Pelaporan, yang dimaksud yaitu upaya pengelola dana desa untuk melaporkan setiap perkembangan kegitan yang sedang dijalankan atau telah diselesaikan kepada pendamping ataupun penanggungjawab dana desa.

5. Pertanggung jawaban keuangan Desa yang dimaksudkan penulis adalah pertanganggung jawaban penggunaan Dana Desa sebagai bentuk laporan hasil realisasi dari penggunaan Dana Desa.

\section{Kendala-Kendala}

Kendala yang dihadapi pemerintah kampung dalam melaksanakan kegiatan pembangunan dan pemberdayaan masyarakat diantaranya : SDM, Swadaya Masyarakat, Pengawasan Masyarakat, Partisipasi Masyarakat dan Perubahan Anggaran.

\section{Hasil Dan Pembahasan}

\subsection{Hasil Penelitian}

\subsubsection{Pengelolaan Keuangan Desa di Kampung Hinekombe Distrik Sentani Kabupaten Jayapura}

\section{Perecanaan Keuangan Kampung Hinekombe Distrik Sentani Kabupaten Jayapura}

Berdasarkan informasi yang diperoleh bahwa Pemerintah Kampung Hinekombe telah mengatur seluruh pengelolaan keuangan desa dengan baik dalam Dokumen RKPK, RPD dan APBDes. Namun dalam pandangan masyarakat masih ada beberapa hal seperti dana pemberdayaan yang terlalu kecil membuat masyarakat merasa belum terbantu dengan adanya dana tersebut. Selain itu juga pembangunan tidak berjalan atau anggaran telah direncanakan namun tidak segera direalisasikan.

\section{Pelaksanaan Pencairan Dana Kampung Hinekombe Distrik Sentani Kabupaten Jayapura}

Proses pelaksanaan keuangan desa merupakan implementasi dari APBDesa yang telah disahkan menjadi Peraturan Desa. Seluruh penerimaan dan pengeluaran pada proses pelaksanaan harus dilaksanakan melalui Reening Kas Desa serta dilegkapi dengan bukti yang lengkap dan sah.. Dari hasil wawancara diperoleh informasi bahwa Realisasi Pencairan Dana Pembangunan dan Pemberdayaan Masyarakat yang telah diatur dalam RKPK dan RPD Kampung Hinekombe selain itu juga telah dilampirkan bukti yang lengkap dan sah. Namun menurun informan lain bahwa Pencairan dana ada beberapa item kegiatan yang tidak dilampirkan bukti pembiayaan dari kegiatan tersebut, jadi terkesan tidak transparan pencairan dana yang dilakukan Pemerintah Kampung Hinekombe.

\section{Penatausahaan Keuangan Kampung Hinekombe Distrik Sentani Kabupaten Jayapura}

Berdasarkan informasi diatas diketahui bahwa Pemerintah Kampung Hinekombe telah melakukan kegiatan penatausahaan dengan cukup baik dimana sudah ada pencatatan penerimaan dana dan pengeluaran dana dalam buku kas bendahara. Namun jika melihat informasi dari masyarakat bahwa kurang begitu tahu tentang pembukuan tersebut menandakan adanya ketidak transparanan dari Pemerintah Kampung HInekombe terkait dokumen pencatatan penerimaan dan pengeluaran dana yang ada di kampung.

\section{Pelaporan Keuangan Kampung Hinekombe Distrik Sentani Kabupaten Jayapura}

Kepala Desa menyusun laporan dengan cara menggabungkan semua laporan kurang dari dua minggu dari bulan Juli tahun berjalan.

\section{Pertanggung Jawaban Keuangan Kampung Hinekombe Distrik Sentani Kabupaten Jayapura}

Dari beberapa informasi diatas dapat dikatakan bahwa Pemerintah Kampung Hinekombe dalam mempertanggung jawabkan pengelolaan dana sudah baik karena setiap tahun anggaran selalu dibuat dokumen APBDes, RKPK, dan RPD baik tahap I dan II. Namun amat disanangkan bahwa masyarakat menanggapi dana dikelola kurang begitu baik karena fakta di masyarakat tidak ada kegiatan pembangunan dan pemberdayaan yang berarti. Artinya dana dikeluarkan setiap tahun tapi tidak sampai kepada masyarakat, ekonomi masyarakat tidak terbantu dengan adanya bantuan dana dari pemerintah.

\subsubsection{Kendala-kendala pengelolaan keuangan desa di Kampung Hinekombe Distrik Sentani Kabupaten Jayapura \\ Sumber Daya Manusia}


Berdasarkan hasil wawancara diatas diketahui bahwa Petugas yang Mengelola Keuangan di Kantor Kampung Hinekombe sudah memiliki SDM yang baik, dimana dapat menyusun setiap laporan kegiatan sesuai dengan pedoman kerja dari Pemerintah Kabupaten Jayapura. Selain itu juga ada beberapa pegawai kantor kampung yang kurang begitu aktif bekerja, atau sering bolos kerja datang terlambat. Akhirnya kegiatan-kegiatan yang telah direncanakan terkadang tidak dapat berjalan karena kekurangan petugas pelaksananya.

\section{Swadaya Masyarakat}

Berdasarkan hasil wawancara diatas, dapat dikatakan bahwa tingkat swadaya masyarakat dalam kaitan pembangunan kampung hinekombe masih kurang. Hal ini disebabkan karena mayoritas masyarakat adalah ekonomi rendah yaitu petani, peternak dan pedagang kecil. Hal ini yang menjadikan masyarakat tidak mampu memberikan bantuan dana kepada pemerintah kampung untuk mendanai kegiatan pembangunan dan pemberdayaan masyarakat di Kampung Hinekombe.

\section{Pengawasan Masyarakat}

Berdasarkan informasi diatas, diketahui bahwa Pengawasan terhadap pengelolaan dana di kampung hinekombe telah dilakukan oleh para tokoh masyarakat di kampung, hal ini karena masyarakat umum mayoritas bekerja sebagai petani, peternak dan pedagang yang dengan kesibukannya tidak dapat memantau setiap aktifitas di kampung. Oleh karenanya adanya tokoh masyarakat sebagai ujung tombak pengawasan kegiatan-kegiatan yang dilaksanakan oleh Pemerintah Kampung Hinekombe.

\section{Partisipasi Masyarakat}

Berdasarkan informasi diatas, dapat dikatakan bahwa masyarakat kampung hinekombe memiliki tingkat partisipasi yang baik dalam setiap kegiatan yang dilakukan Pemerintah Kampung Hinekombe. Seperti kegiatan musyawarah program kerja kampung, yang mana setiap tokoh masyarakat selalu hadir dan menyumbangkan pemikiran mereka tentang apa yang tebaik demi kesejahteraan masarakat di Kampung Hinekombe.

\section{Perubahan Anggaran}

Dari informasi diatas diketahui bahwa dalam kaitan perubahaan anggaran, pemerintah kampung hinekombe segera melakukan penyusunan kebutuhan akan kegiatan-kegiatan yang memerlukan tambahan biaya. Hal ini agar menjaga efektifitas dan efisiensi program-program kerja pemerintah kampung hinekombe. Namun amat sangat disayangkan perubahan tersebut tidak melalui musyawarah kampung, namun sepihak dari aparatur kampung yang menetapkan perubahan anggaran tersebut.

\subsection{Pembahasan}

\section{Pengelolaan Keuangan Desa di Kampung Hinekombe Distrik Sentani Kabupaten Jayapura}

Hasil penelitian menunjukkan bahwa Pemerintah Kampung Hinekombe Distrik Sentani Kabupaten Jaypura sudah cukup baik dalam melakukan pengelolaan keuangan kampung sesuai dengan Peraturan Menteri Dalam Negeri Nomor 20 tahun 2018 Tentang Pengelolaan Keuangan Desa. Hal ini menunjukkan bahwa Pemerintah Kampun Hinekombe telah berusaha bekerja dengan maksimal untuk dapat mengimplementasikan peraturan pemerintah pusat tentang pengelolaan keuangan kampung.

Pertama adalah Perencanaan dimana diketahui bahwa Pemerintah Kampung Hinekombe telah mengatur seluruh pengelolaan keuangan desa dengan baik dalam Dokumen RKPK, RPD dan APBDes. Namun dalam pandangan masyarakat masih ada beberapa hal seperti dana pemberdayaan yang terlalu kecil membuat masyarakat merasa belum terbantu dengan adanya dana tersebut. Selain itu juga pembangunan tidak berjalan atau anggaran telah direncanakan namun tidak segera direalisasikan.

Hal tersebut sesuai dengan Peraturan Menteri Dalam Negeri Nomor 20 tahun 2018 Tentang Pengelolaan Keuangan Desa. Kemudian menurut Bastian (2015) mengatakan bahwa " Aspek yang terkandung dalam perencanaan pembangunan khususnya perencanaan pembangunan kecamatan dan desa, adalah pemusatan tujuan dan cara mencapai tujuan tersebut dengan memanfaatkan sumber daya yang ada".

Berdasarkan penjelasan tentang konsep perencanaan diatas, maka perencanaan dalam penelitian 
ini dapat diartikan sebagai suatu cakupan tindakan atau kegiatan pelaku pengelola keuangan desa dengan maksud tujuan tertentu yakni untuk memecahkan masalah yang ada. Yang mana dokumen perencanaan keuangan desa meliputi RPJMDesa dan RKP Desa yang berpedoman kepada perencanaan pembangunan desa yang disusun berdasarkan hasil kesepakatan dalam musyawarah Desa.

Mengkaji hasil penelitian dimana pada perencanaan pengelolaan keuangan di Kampung Hinekombe telah dilaksanakan sesuai dengan Peraturan Menteri Dalam Negeri Nomor 20 tahun 2018 tentang pengelolaan keuangan desa. Artinya aparatur kampung telah mampu melaksanakan tugastugasnya dalam hal pengelolaan keuangan desa dengan baik. Karena mampu mengikuti peraturan yang telah ditetapkan tentang tata cara dalam perencanaan keuangan di Kampung Hinekombe.

Kedua, Pelaksanaan Pencairan Dana dimana diketahui bahwa Proses pelaksanaan keuangan desa merupakan implementasi dari APBDesa yang telah disahkan menjadi Peraturan Desa. Seluruh penerimaan dan pengeluaran paa proses pelaksanaan harus dilaksanakan melalui Rekning Kas Desa serta dilegkapi dengan bukti yang lengkap dan sah.. Dari hasil wawancara diperoleh informasi bahwa Realisasi Pencairan Dana Pembangunan dan Pemberdayaan Masyarakat yang telah diatur dalam RKPK dan RPD Kampung Hinekombe selain itu juga telah dilampirkan bukti yang lengkap dan sah. Namun menurun informan lain bahwa Pencairan dana ada beberapa item kegiatan yang tidak dilampirkan bukti pembiayaan dari kegiatan tersebut, jadi terkesan tidak transparan pencairan dana yang dilakukan Pemerintah Kampung Hinekombe.

Mengkaji hasil penelitian dimana aparatur kampung telah cukup mampu mengelola keuangan dalam hal pelaksanaan dengan cukup baik. Meskipun masih ada beberapa hal yang perlu diperbaiki seperti lampiran bukti-bukti pengeluaran dana yang ada beberapa tidak ada. Hal ini tentu menjadi evaluasi bagi pihak aparatur kampung agar kedepan setiap pemberkasan dapat dikerjakan dengan lebih maksimal. Mengingat bukti pengeluaran dana amat penting untuk menjaga transparansi dari setiap dana-dana yang dikeluarkan oleh aparatur kampung dalam kegiatan pembangunan di Kampung Hinekombe.

Beberapa tahap yang telah dilakukan oleh aparatur Kampung Hinekombe terkait pengelolaan keuangan pada tahap pelaksanaan yaitu menyusun dokumen Pelaksanaan Anggaran (DPA), Penyusunan RAK Desa, dan Pelaksanaan Kegiatan. Beberapa tahapan dalam pelaksanaan anggaran telah dilakukan walaupun hasil pembangunan belum maksimal. Namun setidaknya ada upaya-upaya yang dilakukan aparatur kampung untuk dapat mengelola anggaran yang ada untuk kesejahteraan masyarakat di Kampung Hinekombe.

Ketiga, Penatausahaan Keuangan Kampung Hinekompe dimana diketahui bahwa Pemerintah Kampung Hinekombe telah melakukan kegiatan penatausahaan dengan cukup baik dimana sudah ada pencatatan penerimaan dana dan pengeluaran dana dalam buku kas bendahara. Namun jika melihat informasi dari masyarakat bahwa kurang begitu tahu tentang pembukuan tersebut menandakan adanya ketidak transparanan dari Pemerintah Kampung HInekombe terkait dokumen pencatatan penerimaan dan pengeluaran dana yang ada di kampung.

Mengkaji hasil penelitian dimana kegiatan penatausahaan dalam pengelolaan keuangan Kampung HInekombe sudah berjalan cukup baik. Artinya aparatur kampung sudah cukup mampu mengelola dana yang ada. Pencatatan uang masuk dan uang keluar sudah dilakukan. Meskipun berdasarkan informasi dari beberapa informan ada beberapa kegiatan yang tidak tercatat bukti kwitansi pengeluarannya. Hal ini tentu apabila tidak segera dilakukan perubahan akan menimbulkan masalah. Karena apabila masyarakat mempertanyakan penggunaan dana. Maka aparatur kampung tidak dapat membuktikan pengeluaran yang dilakukan untuk mendanai kegiatan apa. Walaupun kegiatan benar dilakukan namun karena tidak ada pembuktian dalam bentuk fisik seperti kwitansi pengeluaran uang. Maka akan menjadi masalah dikemudian hari.

Dari penjelasan tersebut terlihat bahwa dalam penatausahaan keuangan maka kepala kampung wajib menetapkan bendahara desa. Dimana penetapan tersebut harus sudah dilakukan sebelum dimulainya tahun anggaran. Terlihat di Kampung Hinekombe sudah ada bendahara yang mengelola keuangan di Kampung Hinekombe. Hal ini akan memudahkan dalam pengelolaan dana yang diterima. Beberapa alat bantu yang digunakan dalam penatausahaan keuangan adalah Buku pembantu bank merupakan catatan penerimaan dan pengeluaran melalui rekening kas Desa. Buku pembantu pajak merupakan catatan penerimaan potongan pajak dan pengeluaran setoran pajak. Buku pembantu panjar merupakan catatan pemberian dan pertanggungjawaban uang panjar. Beberapa buku tersebut menjadi 
kunci dalam penatausahaan keuangan dapat berjalan dengan baik dan transparan.

Keempat, Pelaporan Keuangan diketahui bahwa Laporan pengelolaan dana di Kampung Hinekombe dibuat oleh sekertaris dan berdasarkan data dari bendahara, Laporan tersebut rekapan APBDes, Rencana Penggunaan Dana baik tahap I dan II dan juga Realisasi Kegiatan.

Dapat disimpulkan bahwa pelaporan merupakan kegiatan yang dilakukan untuk menyajikan data dan informasi mengenai suatu kegiatan dalam periode tertentu. Bentuk pelaporan pada kegiatan pengelolaan keuangan desa yakni Kepala Desa menyampaikan laporan realisasi pelaksanaan APB Des kepada Bupati/Walikota. Laporan semester pertama dilaporkan paling lambat akhir bulan Juli dan laporan semester akhir tahun paling lambat akhir bulan Januari tahun berikutnya.

Mengkaji hasil penelitian dimana kegiatna pelaporan penggunaan dana telah rutin dilakukan oleh sekretaris kampung. Baik tahap I, tahap II dan realisasi kegiatan. Hal ini memberikan gambaran bahwa aparatur kampung Hinekombe dalam pengelolaan dana khususnya pada pelaporan sudah dijalankan dengan baik. Karena berpedoman pada peraturan yang ditetapkan pemerintah yaitu Permendagri Nomor 20 tahun 2018 Tentang Pengelolaan Keuangan Desa.

Dengan adanya pelaporan yang baik dari pihak Kampung Hinekombe ke Pemerintah Kabupaten Jayapura yang selanjutnya menjadi bahan evaluasi dari pemerintah untuk tahun anggaran berikutnya. Selain itu juga melihat pencapaian pembangunan kampung yang mana diberikan dana untuk kegiatan pembangunan dan pemberdayaan masyarakat setiap tahunnya. Dengan demikian dapat dikatakan bahwa aparatur Kampung Hinekombe telah mampu mengelola keuangan kampung pada sisi pelaporan dengan baik.

Kelima, Pertanggung jawaban diketahui bahwa Pemerintah Kampung Hinekombe dalam mempertanggung jawabkan pengelolaan dana sudah baik karena setiap tahun anggaran selalu dibuat dokumen APBDes, RKPK, dan RPD baik tahap I dan II. Namun amat disanangkan bahwa masyarakat menanggapi dana dikelola kurang begitu baik karena fakta di masyarakat tidak ada kegiatan pembangunan dan pemberdayaan yang berarti. Artinya dana dikeluarkan setiap tahun tapi tidak sampai kepada masyarakat, ekonomi masyarakat tidak terbantu dengan adanya bantuan dana dari pemerintah.

Mengkaji hasil penelitian dimana pelaksanaan tahap pertanggung jawaban oleh aparatur Kampung Hinekombe sudah baik artinya aparatur kampung mampu mengikuti pedoman tentang pengelolaan keuangan desa sesuai dengan peraturan pemerintah dalam Peraturan Menteri Dalam Negeri Nomor 20 tahun 2018 Tentang Pengelolaan Keuangan Desa. Ini memberikan gambaran bahwa dengan adanya pertanggung jawaban yang baik maka akan mendukung proses percepatan pembangunan dan pemberdayaan masyarakat di Kampung Hinekombe. Oleh karena pengelolaan keuangan telah dilakukan secara transparan dan dapat dipertanggungjawabkan. Selain itu juga pemerintah akan dapat melihat perkembangan pencapaian pembangunan yang dilakukan di tingkat kampung.

\section{Kendala-kendala Pengelolaan Keuangan Desa di Kampung Hinekombe Distrik Sentani Kabupaten Jayapura}

Hasil penelitian menunjukkan bahwa kendala-kendala yang dihadapi dalam kaitannya pengelolaan keuangan desa di Kampung Hinekombe Distrik Sentani Kabupaten Jayapura yaitu Swadaya Masyarakat masih kurang, pengawasan juga masih kurang. Selain itu juga perubahan anggaran tidak dilakukan melalui musyawarah dengan tokoh masyarakat atau sepihak oleh Aparatur Pemerintah Kampung Hinekombe yang membuat masyarakat kurang begitu percaya terhadap pengelolaan keuangan yang dilakukan pemerintah kampung hinekombe.

Petugas yang mengelola Keuangan di Kantor Kampung Hinekombe sudah memiliki SDM yang baik, dimana dapat menyusun setiap laporan kegiatan sesuai dengan pedoman kerja dari Pemerintah Kabupaten Jayapura. Selain itu juga ada beberapa pegawai kantor kampung yang kurang begitu aktif bekerja, atau sering bolos kerja datang terlambat. Akhirnya kegiatan-kegiatan yang telah direncanakan terkadang tidak dapat berjalan karena kekurangan petugas pelaksananya.

Secara khusus, desa memainkan peran penting dalam menyediakan layanan infrastruktur pedesaan dan terlibat dalam kegiatan penurunan kemiskinan, kesejahteraan sosial, pendidikan dasar, dan kesejahteraan publik. Untuk mendukung tugas pemerintah desa dalam melakukan pengelolaan keuangan desa, maka Perlu adanya swadaya masyarakat untuk mendukung pendanaan kegiatankegiatan pembangunan di kampung. 
pada lokasi penelitian terlihat bahwa tingkat swadaya masyarakat dalam kaitan pembangunan kampung hinekombe masih kurang. Hal ini disebabkan karena mayoritas masyarakat adalah ekonomi rendah yaitu petani, peternak dan pedagang kecil. Hal ini yang menjadikan masyarakat tidak mampu memberikan bantuan dana kepada pemerintah kampung untuk mendanai kegiatan pembangunan dan pemberdayaan masyarakat di Kampung Hinekombe.

Pengawasan terhadap pengelolaan dana di kampung hinekombe telah dilakukan oleh para tokoh masyarakat di kampung, hal ini karena masyarakat umum mayoritas bekerja sebagai petani, peternak dan pedagang yang dengan kesibukannya tidak dapat memantau setiap aktifitas di kampung. Oleh karenanya adanya tokoh masyarakat sebagai ujung tombak pengawasan kegiatan-kegiatan yang dilaksanakan oleh Pemerintah Kampung Hinekombe.

Masyarakat kampung hinekombe memiliki tingkat partisipasi yang baik dalam setiap kegiatan yang dilakukan Pemerintah Kampung Hinekombe. Seperti kegiatan musyawarah program kerja kampung, yang mana setiap tokoh masyarakat selalu hadir dan menyumbangkan pemikiran mereka tentang apa yang tebaik demi kesejahteraan masarakat di Kampung Hinekombe.

Dalam Kaitan perubahaan anggaran, pemerintah kampung hinekombe segera melakukan penyusunan kebutuhan akan kegiatan-kegiatan yang memerlukan tambahan biaya. Hal ini agar menjaga efektifitas dan efisiensi program-program kerja pemerintah kampung hinekombe. Namun amat sangat disayangkan perubahan tersebut tidak melalui musyawarah kampung, namun sepihak dari aparatur kampung yang menetapkan perubahan anggaran tersebut.

\section{Penutup}

\subsection{Kesimpulan}

Adapun kesimpulan yang dapat ditarik dari penelitian ini, antara lain:

1. Pengelolaan keuangan desa di Kampung Hinekombe Distrik Sentani Kabupaten Jayapura telah cukup baik sesuai dengan Peraturan Menteri Dalam Negeri Nomor 20 tahun 2018 Tentang Pengelolaan Keuangan Desa.

2. Kendala-kendala yang dihadapi pemerintah kampung dalam pengelolaan keuangan di Kampung Hinekombe Distrik Sentani Kabupaten Jayapura.yaitu Swadaya Masyarakat masih kurang, pengawasan juga masih kurang. Selain itu juga perubahan anggaran tidak dilakukan melalui musyawarah dengan tokoh masyarakat atau sepihak oleh Aparatur Pemerintah Kampung Hinekombe yang membuat masyarakat kurang begitu percaya terhadap pengelolaan keuangan yang dilakukan pemerintah kampung hinekombe.

\subsection{Saran}

Beberapa saran yang dapat penulis sampaikan adalah sebagai berikut :

1. Pemerintah Kampung Hinekombe

Agar lebih memperhatikan aspirasi masyarakat dalam setiap penyusunan program kerja pemerintah kampung yang menggunakan dana keuangan desa. Agar pembangunan dapat dirasakan masyarakat dan sesuai dengan apa yang diharapkan masyarakat kampung hinekombe.

2. Masyarakat Kampung

Agar lebih meningkatkan pengawasan kegiatan pembangunan di kampung serta pengelolaan keuangan agar pencairan dana pada APBDes dapat sesuai dengan implementasi di lapangan serta dapat bermanfaat bagi masyarakat.

3. Peneliti selanjutnya

Penelitian penulis dapat menjadi referensi bagi penelitian selanjutnya bila melakukan penelitian sejenis berkaitan dengan pengelolaan keuangan desa.

\section{Daftar Pustaka}

Bastian, I. (2015). Akuntansi untuk Kecamatan \& Desa. Jakarta: Erlangga.

Hutami, A. S. S. (2017). Analisis Pengelolaan Alokasi Dana Desa (ADD) di Desa Abbatireng Kecamatan Gilireng, Kabupaten Wajo. Government: Jurnal Ilmu Pemerintahan, 10-19.

Lili, M. A. (2018). Pengelolaan Alokasi Dana Desa Dalam Upaya Meningkatkan Pembangunan Ekonomi Masyarakat di Desa Magmagan Karya Kecamatan Lumar. Jurnal Ekonomi Daerah 
(JEDA), 7(1).

Peraturan Menteri Dalam Negeri Nomor 113 Tahun 2014. Tentang Pengelolaan Keuangan Desa. , Jakarta: Kementerian Dalam Negeri Republik Indonesia §.

Peraturan Menteri Dalam Negeri Nomor 20 tahun 2018. Tentang Pengelolaan Keuangan Desa., Jakarta: Kementerian Dalam Negeri Republik Indonesia §.

Prabowo, B. A. (2007). Pengaruh Anggaran Berbasis Kinerja Terhadap Efektivitas Belanja Operasional (Studi Kasus pada Dinas Tenaga Kerja dan Transmigrasi Provinsi Jawa Barat). Universitas Widyatama.

Pradana, H. Y. (2018). Analisis Penerapan Pengelolaan Keuangan Desa Berdasarkan Peraturan Menteri Dalam Negeri Nomor 113 Tahun 2014 (Studi Kasus di Desa Jatimulyo Kecamatan Girimulyo Kabupaten Kulon Progo). Universitas Sanata Dharma.

Shuha, K. (2018). Analisis Pengelolaan Dana Desa (Studi Kasus pada Desa-desa Selingkungan Kecamatan Lubuk Alung Kabupaten Padang Pariaman). Jurnal Akuntansi, 6(2).

Wardoyo. (1980). Kamus Besar Bahasa Indonesia. Balai Jakarta.

Winarni, F., \& Yuanjaya, P. (2016). Implementasi Kebijakan Dana Desa Dalam Meningkatan Pembangunan Di Desa Wukirsari, Kabupaten Sleman. Jurnal Natapraja: Kajian Ilmu Administrasi Negara, 4(1). 